Szegedi Tudományegyetem, Belgyógyászati Klinika, Szeged, ${ }^{1}$ Szegedi Tudományegyetem, Farmakológiai és Farmakoterápiai Intézet, Szeged, ${ }^{2}$ Semmelweis Egyetem, Belgyógyászati és Onkológiai Klinika, Budapest ${ }^{3}$

\title{
Inzulinpumpa-kezelést igénylő, kedvezőtlen anyagcsere-állapotú 1-es típusú diabeteses betegek autonóm idegrendszeri funkciójának jellemzői
}

\author{
Magony Sándor dr., ${ }^{(1)}$ Nyiraty Szabolcs dr., ${ }^{(1)}$ Fehértemplomi Katalin dr., \\ Tóth Bettina dr., ${ }^{(1)}$ Pesei Fruzsina dr., ${ }^{(1)}$ Orosz Andrea dr., ${ }^{(2)}$ \\ Lengyel Csaba dr., ${ }^{(1)}$ Kempler Péter dr., ${ }^{(3)}$ Várkonyi Tamás dr. ${ }^{(1)}$
}

\begin{abstract}
Osszefoglalás
Bevezetés: A szénhidrát-anyagcsere súlyos instabilitása csökken inzulinpumpa bevezetése után 1-es típusú diabetesben. A glükózanyagcsere zavara autonóm neuropathiát okozhat, azonban az autonóm károsodás is felelös lehet az anyagcsere romlásáért. Felmerül a kérdés, hogy milyen mértékü az autonóm idegrendszer érintettsége a pumpakezelés indikációjának megfelelö rossz anyagcsere mellett, továbbá a neuropathia javulása akár rövid idön belül bekövetkezik-e a pumpakezelés megkezdése után. Célkitüzés: Vizsgálataink célja a kardiovaszkuláris autonóm funkció jellemzése volt pumpakezelés megkezdésekor, majd a kezelés bevezetése után 2 hónappal. Betegek, módszerek: Vizsgálatainkba 1-es típusú diabete-

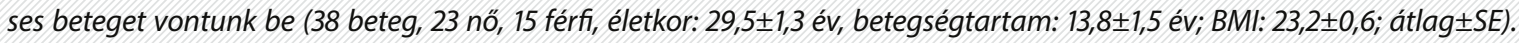
A kontrollcsoportba 10 nem diabeteses személy került (életkor: $27,8 \pm 2$ év). Az autonóm neuropathia (AN) vizsgálatát az inzulinpumpa felhelyezése elött és azt követöen 2 hónappal kardiovaszkuláris reflextesztek (CRT) segitségével végeztük el. Eredmények: A betegcsoportban a legérzékenyebb paraszimpatikus teszt, a belégzésre bekövetkezö szivfrekvencia-változás az egészséges kontrollhoz képest szignifikánsan kórosnak bizonyult a kezelés kezdetén (belégzés: $32,6 \pm 3,8$ vs. 18,6 1,5 ütés/min., $p<0,001)$. A paraszimpatikus károsodás mértéke annál kifejezettebb volt, minél hosszabb volt a bólus-bázis inzulinkezelés idötartama az inzulinpumpa felhelyezése elött a betegekben (AN score-tartam: $r=0,51, p<0,05$; belégzés-tartam: $r=-0,63, p<0,001$ ). A két hónapos pumpakezelés mellett az AN összesitett súlyossága csökkent (AN score: 2,2 $\pm 0,2$ vs.

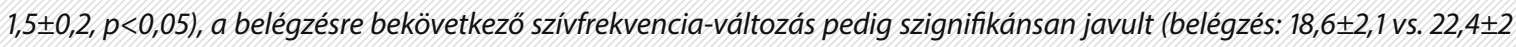
ütés/min., $p<0,05)$. Az átlagos $H b A_{1 c}$ a két hónapos kezelés alatt $0,7 \%$-ot csökkent $(8,7 \pm 0,2 \%$ vs. $8,0 \pm 0,3 \%, p=0,125)$. Következtetés: A pumpakezelés megkezdésekor a fiatal 1-es típusú diabeteses betegekben a paraszimpatikus idegrendszeri diszfunkció dominált, ami már két hónapos pumpakezelés mellett javulást mutatott. Az idegrendszeri érintettség súlyossága szoros összefüggést mutatott a pumpakezelést megelözö bólus-bázis inzulinkezelés idötartamával. Adataink 1-es típusú diabetes mellitusban megerösitik azt a megfigyelést, hogy kóros szénhidrát-anyagcsere esetén a paraszimpatikus idegrendszer károsodik elsöként, ami eredményeink szerint a pumpakezelés elkezdését követöen már rövid idön belül is javulhat.

Kulcsszavak: 1-es típusú diabetes, inzulinpumpa-kezelés, autonóm neuropathia
\end{abstract}

Közlésre érkezett: 2020. október 12. • Közlésre elfogadva: 2020. november 30.

A levelezésért felelős szerző: Dr. Magony Sándor

SZTE, Belgyógyászati Klinika

6725 Szeged, Kálvária sgt. 57.

E-mail: magony.sandor@med.u-szeged.hu 


\section{Characteristics of autonomic neuronal function of type 1 diabetic patients with poor glycemic control at the initiation of insulin pump treatment}

Summary: Introduction: Insulin pump treatment is introduced due to the severe instability of glycemic control in type 1 diabetes (DM). Unstable glucose metabolism leads to the development and progression of autonomic neuropathy (AN) in these patients, while AN may improve even within a short period of better glycemic control. Objectives: The aim of our study was to describe the characteristics of the cardiovascular autonomic function at initiation of insulin pump treatment and 2 months later. Methods: 38 type 1 DM patients were involved ( 23 women, 15 men, age: $29.5 \pm 1.3$ years, duration of DM: $13.8 \pm 1.5$ years; $B M I: 23.2 \pm 0.6$; mean $\pm S E$ ). 10 non diabetic subjects were enrolled as a control group (age: $27.8 \pm 2$ years). Autonomic neuropathy (AN) was assessed at the first application of insulin pump and 2 months later by cardiovascular reflex tests (CRT). Results: The most sensitive parasympathetic test, the heart rate response to breathing was significantly impaired in type 1DM patients compared to healthy controls (breathing: $32.6 \pm 3.8 \mathrm{vs}$. 18.6 \pm 1.5 beats $/ \mathrm{min}, p<0.001$ ). Longer duration of bolus-basal insulin treatment correlated with more severe parasympathetic dysfunction (AN score-duration: $r=0.51, p<0.05$; breathing-duration: $r=-0.63, p<0.001$ ). The overall severity of AN reduced (AN score: $2.2 \pm 0.2 v s$. $1.5 \pm 0.2$, $p<0.05)$ and the heart rate response to breathing significantly improved two months after the initiation of insulin pump treatment (breathing: $18.6 \pm 2.1$ vs. $22.4 \pm 2$ beats/min, $p<0.05$ ). The mean $\mathrm{HbA}_{1 \mathrm{c}}$ decreased by $0.7 \%$ during the two-month treatment period $(8.7 \pm 0.2 \%$ vs. $8.0 \pm 0.3 \%, p=0.125)$. Conclusion: Moderate to severe autonomic neuropathy was found in type 1 diabetic patients at the initiation of insulin pump treatment which improved after two months of treatment. The severity of the parasympathetic involvement strictly correlated with the duration of the bolus-basal insulin treatment. Our data confirm the theory that in type 1 diabetes the parasympathetic function is impaired earlier during the progression of the metabolic disease and might improve after a short-term insulin pump treatment.

Key words: type 1 diabetes, insulin pump treatment, autonomic neuropathy

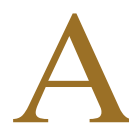
z autonóm neuropathia a mortalitás önálló rizikófaktora 1-es típusú diabetesben, aminek oka többek között a szimpatikus idegrendszer fokozott aktivitása, a kardiovaszkuláris adaptáció zavara, a diastolés diszfunkció létrejötte, valamint a fokozott aritmiakészség lehet, amelyek a hirtelen szívhalál vagy légzésleállás kialakulásának fontos etiológiai tényezői. ${ }^{1}$ Ezek az adatok felhívják a figyelmet arra, hogy minden terápiás lehetőséget igénybe kell vennünk ahhoz, hogy megelőzzük a szív-érrendszer állapotát döntően meghatározó autonóm neuropathia kialakulását vagy progresszióját, biztosítva ezzel a korai mortalitás csökkentését. 1-es típusú diabetesben ennek leghatékonyabb eszköze minden kétséget kizáróan a minél inkább hatékony anyagcsere-beállítás, aminek elérése után várható, hogy a neuropathia kisebb kockázattal fejti ki hátrányos hatását. Nem ismert, hogy az anyagcsere-optimalizálás milyen időtartamon belül fejti ki előnyös hatását az autonóm idegrendszer működésére, jóllehet a betegellátásban segítséget jelentene számunkra, hogy betegünk szövődménystátuszát pontosabban tudjuk megítélni. A hosszú távú glykaemiás kontroll és a neuropathia gyakorisága közötti összefüggésre számos korábbi vizsgálat rávilágított már. E kérdés egyik úttörője, Pirart több mint 40 éve, 1977-ben közölte megfigyeléseit, amelyek során 25 éven keresztül követett mintegy 4400 cukorbeteget, dokumentálva a rendszeres ellenőrzések során talált éhomi és posztprandiális vércukorértékeket, a glucosuria mértékét, valamint az ezen idő alatt megfigyelt ketoacidosisos epizódokat és a betegek panaszait. Eredményei igazolták, hogy a retinopathia, a nephropathia és a neuropathia kialakulásának gyakorisága nem(csak) a diabetes tartamától, hanem az anyagcsere-beállítás minőségétől is függ. ${ }^{2}$ A DCCT-EDIC követéses vizsgálat eredményei igazolták a korai intenzív kezelés hosszú távú jótékony hatását a neuropathia incidenciájára és progressziójára. A mintegy 20 éves követés során azt találták, hogy a szívfrekvencia variabilitása, amelyet az EKG R-R hullámainak elemzése révén rögzítettek, kisebb mértékű paraszimpatikus károsodást igazolt az intenzív inzulinkezelésben korán részesülő betegekben 1-es típusú diabetesben. A felhasznált metodika a legkorábban jelzi a paraszimpatikus funkció esetleges romlását., ${ }^{3,4} \mathrm{Az}$ EURODIAB-IDDM 
mérföldkő fontosságú vizsgálat az autonóm neuropathia számos rizikófaktorát igazolta 1-es típusú diabetesben, amelyek közé a hosszú távú glykaemiás kontroll és a diabetestartam is tartozik. ${ }^{5}$ A UKPDS pedig 2-es típusú diabetesben tette egyértelművé, hogy az intenzív anyagcserekezelés mellett a neuropathiás szövődmények relatív kockázata (biothesiometerrel mérve) csökkent a megfigyelés 9., illetve 15 . évére. ${ }^{6}$ Néhány vizsgálati adat, jóval kisebb betegszámú tanulmányokban, mint az előbbiekben említett vizsgálatokban, amellett szól, hogy már rövid távú glükózszintváltozás is befolyásolhatja az idegrendszeri funkciókat. 8 hónappal a subcutan pumpakezelés megkezdése után a konzervativ inzulinkezelésben részesülőkhöz képest a perifériás idegvezetéses eredmények már javulást mutattak. ${ }^{7}$ 4 héttel az intenzív inzulinkezelés megkezdését követően az idegvezetési paraméterek és az axonális szintủ ingerületvezetés javulását találták japán cukorbetegekben. ${ }^{8} 20$ napos konzekvensen fenntartott normoglykaemia mellett 2-es típusú diabetesben a vibrációérzet kétféle metodikával vizsgálva is javulást mutatott az alsó és a felső végtagokon. ${ }^{9}$ Experimentális körülmények között clamp vizsgálatban létrehozott 2 órás hyperglykaemia alatt az EKG-t monitorizálva a QT idő aktuális növekedését észlelték 2-es típusú diabeteses betegekben, amihez az autonóm idegrendszer instabilitását tükröző fokozott szimpatikus aktivitást is rögzítettek. ${ }^{10}$ Egészséges személyekben is megfigyelték a 2 órás, átmeneti $15 \mathrm{mmol} / \mathrm{l}$-es vércukorérték kamrai repolariációt rontó és katecholaminszintet emelő hatását. ${ }^{11}$ Egészséges emberekben 150 percen keresztül létrehozott arteficiális hyperglykaemia esetén a nyugalmi szívfrekvencia fokozódását és a felállásra bekövetkező szívfrekvencia-válasz kórossá válását igazolták, ami a magas vércukorszint paraszimpatikus rendszerre kifejtett akut hatását igazolja. ${ }^{12}$ Egészséges személyekben a pancreas-polipeptid bazális és stimulált szekréciója egyaránt csökkent kísérletes körülmények közötti hyperglykaemia esetén, ami szintén a vagális cholinerg működés romlását jelzi akkor, ha a vércukor aktuálisan magas. ${ }^{13}$ $\mathrm{Az}$ irodalmi adatok egyértelműen arra utalnak, hogy a tartósan ideális anyagcsere hosszú távon előnyös lehet az autonóm neuropathia prevenciójában és a progresszió csökkentésében. A rövid távú, pár napos-hetes normoglykaemia, illetve a hyperglykaemia idegrendszerre kifejtett aktuális hatásáról szóló adatok felvetik a kérdést, hogy az anyagcsere-stabilizálás mennyi idő eltelte után hoz eredményt ebből a szempontból. 1-es típusú diabetesben a legintenzívebb kezelés és az optimalizálás leghatékonyabb formája a subcutan pumpakezelés bevezetése. A fentiek ismeretében elvégeztünk egy vizsgálatot, amelyben az inzulinpumpa-kezelés előtt, majd azt követően rövid időn belül megvizsgáltuk a kardiovaszkuláris autonóm idegrendszer funkcióját fiatal, 1-es típusú diabeteses betegekben. Vizsgálatunk célja annak felderítése volt, hogy pumpafelhelyezés kezdetén melyek a kardiovaszkuláris autonóm idegrendszeri működés jellemzői, és ezek hogyan változnak 2 hónapos pumpakezelést követően. Mindezek mellett összefüggést kerestünk a diabetest jellemző paraméterek és az autonóm idegrendszer funkciója között.

\section{Betegek és módszerek}

Vizsgálatainkban 38 (23 nő és 15 férfi) 1-es típusú diabeteses beteg és 10 egészséges kontrollszemély (6 nő és 4 férfi) vett részt. A betegek a vizsgálatok elvégzésekor átlagban fiatal felnőtt korúak voltak (29,5 $\pm 1,3$ év, átlag \pm SE), betegségük gyermek- vagy pubertáskorban kezdődött (diabetestartam: 13,8 $\pm 1,5$ év), valamennyi beteg a diagnózist követően rögtön inzulinkezelésben részesült. Testtömegindexük szerint a normális tartományba tartoztak, a BMI-értékük 23,2 $\pm 0,6$ volt. Az első autonóm idegrendszeri vizsgálatra minden beteg esetében akkor került sor, amikor megkezdődött inzulinpumpa-kezelésük. Vércukor-ingadozásuk jelentős volt, gyakran haladta meg a napi $10 \mathrm{mmol} / \mathrm{l}-\mathrm{t}$ a változás mértéke (24/38 beteg), illetve a $\mathrm{HbA}_{1 c}$-értékük minden beteg esetében magasabb volt, mint $8 \%$ (38/38 beteg), a vizsgálat kezdetekor az átlagos $\mathrm{HbA}_{1 \mathrm{c}}$ $8,7 \% \pm 0,2$ volt a betegcsoportban. 6 beteg esetében a szövődmények gyors progresszióját észleltük, 2 nőbeteg esetében a pumpakezelés fentieken túli indikációja mellett fertilitási igény is volt. A diabeteshez társuló szövődmények előfordulási gyakorisága a vizsgálatba bevont betegek körében: retinopathia 16 , nephropathia 10, igazolt diabeteses neuropathia 10 beteg esetében állt fenn. Az anamnézis szerint 1-1 betegnek volt korábban myocardialis infarctusa, illetve agyi éreredetű eseménye. Az autonóm funkciót felmérő második vizsgálat 2 hónappal a pumpa 
felhelyezése után történt. A betegeknél mind a két vizsgálat alkalmával történt $\mathrm{HbA}_{1 c}$-meghatározás.

A kontrollcsoport tagjai a leíró paraméterek vonatkozásában nem különböztek szignifikánsan a betegcsoporttól. Az átlagéletkor 27,8 \pm 2 év, a BMI-érték pedig $24,1 \pm 0,4$ volt.

\section{A vizsgálathoz használt módszerek}

Az autonóm neuropathia jelenlétét és súlyosságát a Ewing és munkatársai által leírt 4 standard kardiovaszkuláris reflexteszttel jellemeztük. ${ }^{14}$

Az általunk alkalmazott reflexteszteket, valamint azok normális és kóros értékeit az 1. táblázat foglalja össze.

\section{A szívfrekvencia-változást vizsgáló tesztek}

1. Mély légzést kísérő szívfrekvencia-változások: Fiziológiásan a szívfrekvenciának a légzéssel szinkron változásai figyelhetők meg, amit légzési aritmiaként ismerünk. Belégzés során nő, kilégzés alatt csökken a szívfrekvencia. Diabetesben kardiovaszkuláris autonóm neuropathia fennállása esetén ez a légzésre bekövetkező szívfrekvencia-variabilitás csökken, vagy meg is szűnik. A szívfrekvencia maximális változása egészséges egyénekben akkor figyelhető meg, ha a légzési periódus (be- és kilégzés együttvéve) 6/perc körül van. Vizsgálata: A vizsgált személy fekvő helyzetben 6/perc légzési frekvenciával mély be- és kilégzést végez 30 másodpercig (5-5 másodpercig tartó be- és kilégzés), miközben folyamatos EKG-vizsgálat készül. Ezáltal meghatározhatjuk a belégzés alatti legrövidebb, valamint a kilégzés alatti leghosszabb RR távolság közötti különbséget. A 15/perc feletti frekvencia-különbség normálisnak, a 11-14/perc közötti határesetnek, a 10/perc alatti pedig kórosnak számít.

2. A Valsalva-manővert kísérő szívfrekvenciaváltozások: A Valsalva-manőver zárt epiglottis melletti erőltetett kilégzés, amely közben a hasűri és mellüregi nyomás emelkedik, és ez a vagus által közvetített paraszimpatikus funkción keresztül hat a szív működésére. Fiziológiás esetben a manőver végzése közben a vérnyomás csökken, a szívfrekvencia pedig nő. Közvetlenül a manőver után teljesen ellentétes állapot, vérnyomás-emelkedés figyelhető meg - ami eléri, majd meghaladja a manőver előtti értéket -, miközben a szívfrekvencia csökken a vagális baroreflex miatt. Vizsgálata: A vizsgált személynek 40 Hgmmes nyomást tartva 15 másodpercig kell fújnia egy klasszikus vérnyomásmérővel összekötött gumicsőbe. A manőver alatt folyamatosan, majd utána 1 percen keresztül EKG-felvétel készül. Az erőltetett kilégzést követő leghoszszabb és a manőver alatti lerövidebb RR távolság hányadosa adja a Valsalva-hányadost. Normálértéknek az 1,21 vagy nagyobb, határértéknek az 1,20-1,11 közötti, míg kórosnak az 1,10 alatti érték tekinthető.

3. Felállás után bekövetkező szívfrekvencia-változások (30:15 hányados): Egészséges egyénekben fekvésből történő felállást követően a szívfrekvencia átmenetileg nő, majd ezután csökkenni kezd. A maximális szívfrekvencia a felállást követő 15 . szívverésnél, a legalacsonyabb pedig a 30 . környékén észlelhető.

1. táblázat. A kardiovaszkuláris reflextesztek normális értékei Ewing és munkatársai nyomán (forrás: Kempler Péter, Várkonyi Tamás: Neuropathiák a klinikai gyakorlatban, 98. o. ISBN 978-615-50 052-2-0)

\begin{tabular}{|c|c|c|c|c|}
\hline Módszer & Mért érték & Normális érték & Határérték & Káros érték \\
\hline \multicolumn{5}{|c|}{ Paraszimpatikus funkciót vizsgáló tesztek } \\
\hline Mély be- és kilégzés & Beat-to-beat variáció (ütés/perc) & $\geq 15$ & $11-14$ & $\leq 10$ \\
\hline Valsalva-manőver & Valsalva-hányados & $\geq 1,21$ & $1,11-1,20$ & $\leq 1,10$ \\
\hline Felállás & 30:15 hányados & $\geq 1,04$ & $1,01-1,03$ & $\leq 1,00$ \\
\hline \multicolumn{5}{|c|}{ Szimpatikus funkciót vizsgáló tesztek } \\
\hline Felállás & Systolés vérnyomáscsökkenés (Hgmm) & $<10$ & $11-29$ & $\geq 30$ \\
\hline Handgrip teszt & Diastolés vérnyomáscsökkenés (Hgmm) & $>16$ & $11-15$ & $\leq 10$ \\
\hline
\end{tabular}


Vizsgálata: A vizsgált személy 5 percig nyugalomban fekszik, majd feláll úgy, hogy a karjait a teste mellett lazán lógatva tartja. Ezt a testhelyzetet 1 percig tartja, miközben folyamatosan EKG-felvétel készül a fekvéstől kezdődően, amelyből meghatározzuk a felkeléstől számított 15. szívverés körüli legrövidebb RR távolság (maximális frekvencia-növekedés) és a 30. ütés körüli leghosszabb RR távolság (maximális frekvencia-csökkenés) hányadosát. Normálérték az 1,04 vagy nagyobb hányados, határérték az 1,01-1,03 közötti, míg kóros az 1,00 alatti érték.

\section{Vérnyomásváltozást vizsgáló teszt}

Felállást követő systolés vérnyomáscsökkenés: Normál körülmények között a felállást követően különböző reflexmechanizmusok lépnek működésbe a gravitáció következtében az alsó végtagokba kerülő vérnek a test felsőbb részeibe pumpálása érdekében. A szívfrekvencia növekedésén kívül a vérnyomás is hirtelen, rövid ideig nő, majd gyorsan csökkenni kezd. Az autonóm neuropathia következtében a splanchnikus erek vasoconstrictiója elmarad, aminek következményeként felállás után hirtelen vérnyomásesés, orthostaticus hypotonia alakul ki, ami akár ájulást is okozhat.

Vizsgálata: A vizsgált személy 10 percig nyugalomban fekszik, majd ezt követően feláll. A felállást követő 1 ., 5. és 10 . percben vérnyomásmérés történik. Normális, nem károsodott autonóm funkciót jelez, ha a systolés vérnyomásérték kevesebb mint 10 Hgmm-rel csökken a felállás után. Ha a vérnyomásesés $10 \mathrm{Hgmm}$ és $30 \mathrm{Hgmm}$ közötti, az határértéknek számít, ha a vérnyomásesés meghaladja a $30 \mathrm{Hgmm}-\mathrm{t}$, akkor a teszt kóros, és az a szimpatikus beidegzés súlyos zavarára utal.

\section{Autonóm score}

Az egyes kardiovaszkuláris reflextesztek után kapott értékeket összesítettük, és 0-tól 8-ig terjedő skálával jellemeztük az autonóm neuropathia súlyosságát, amit autonóm score-ként fejeztünk ki. $\mathrm{Az}$ egyes tesztek esetében a normális tartományba eső érték 0 pont, a határérték tartományba eső 1 pont, míg a kóros tartományba eső 2 pontot jelent. Az 4 reflexteszt alapján összesen $0-1$ pont felel meg a szövődménymentes kategóriának. 2-3 pont esetén már az autonóm neuropathia enyhe jelei mutatkoznak. A kifejezett, nem súlyos neuropathia 4-6 pont közötti, a súlyos neuropathia pedig 7 pont feletti értékkel jellemezhető.

\section{Eredmények}

Az 1-es típusú diabetes tartama a pumpafelhelyezés idejéig erős pozitív, szignifikáns korrelációt

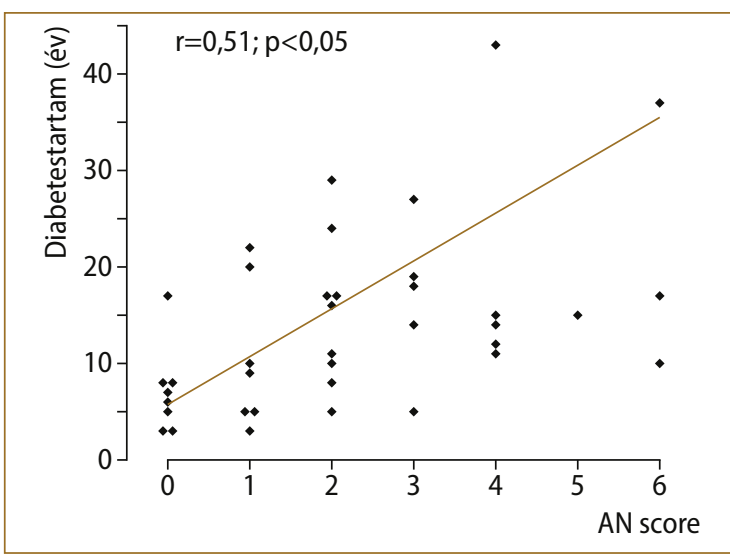

1. ábra. Összefüggés a diabetestartam és az autonóm neuropathia (AN) score között 1-es típusú diabeteses betegekben inzulinpumpa felhelyezésekor

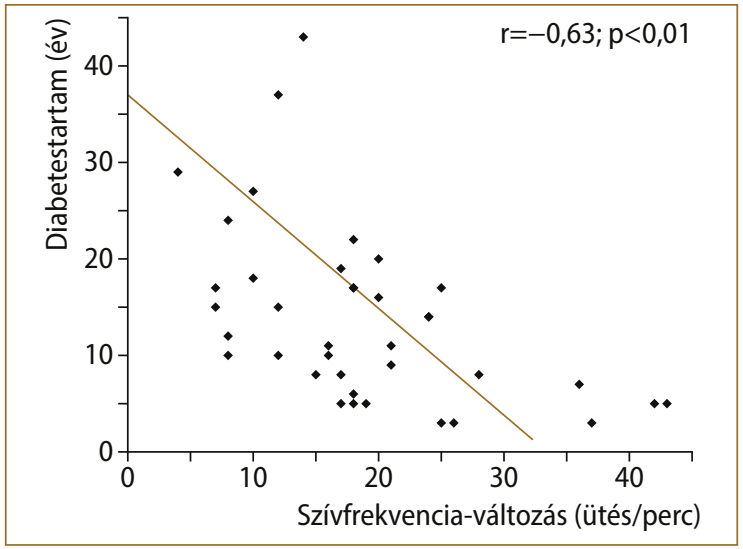

2. ábra. Összefüggés a diabetestartam és a légzésre bekövetkező szívfrekvencia-változás között 1-es típusú diabeteses betegekben inzulinpumpa felhelyezésekor 


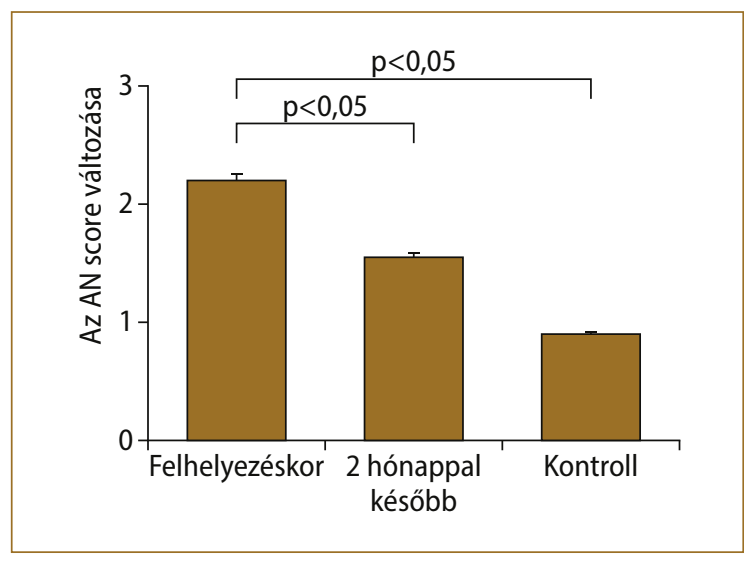

3. ábra. Az autonóm neuropathia (AN) score változása a diabeteses betegekben és a kontrollcsoport értéke

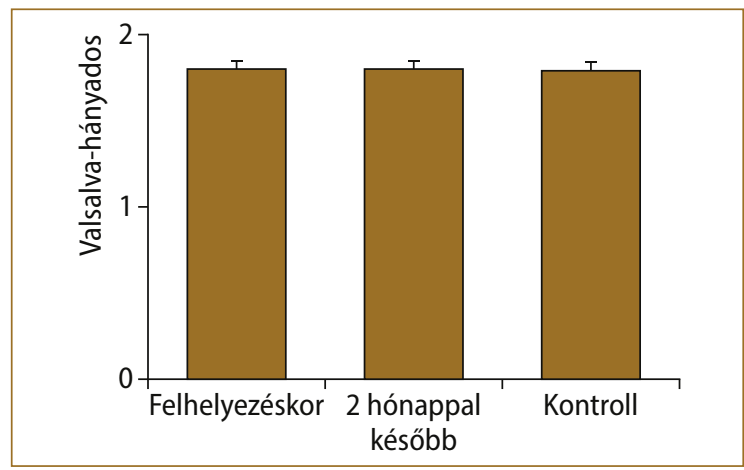

5. ábra. A Valsalva-hányados változása inzulinpumpával kezelt diabeteses betegekben és a kontrollcsoport értéke

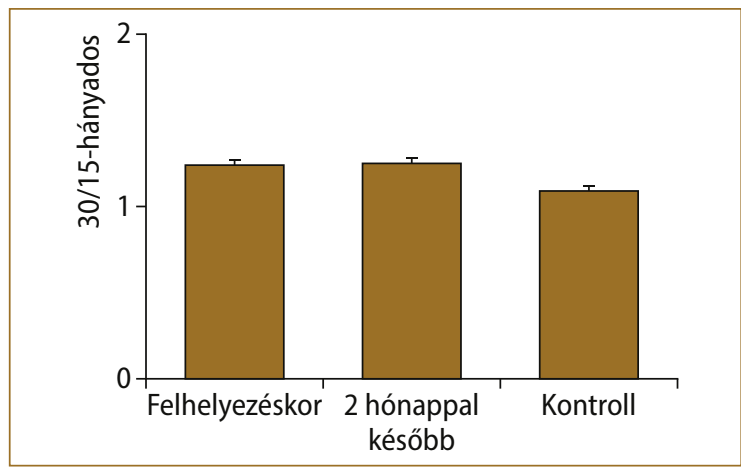

6. ábra. A 30/15 hányados változása inzulinpumpával kezelt diabeteses betegekben és a kontrollcsoport értéke

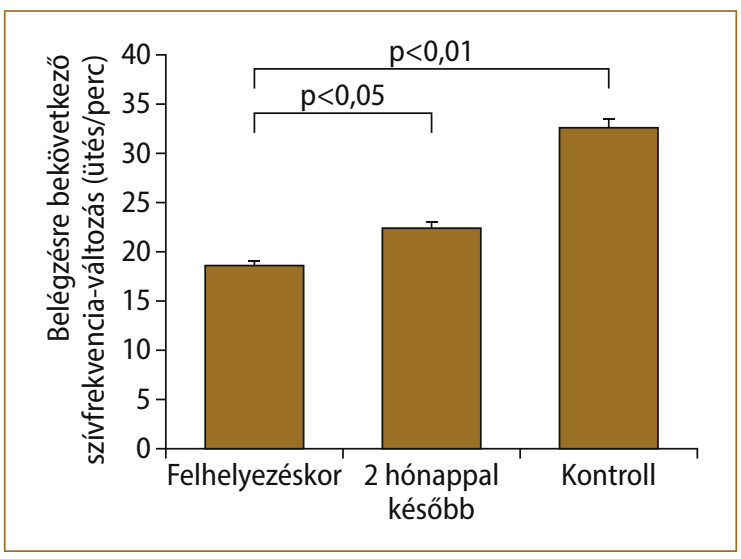

4. ábra. A belégzésre létrejövő szívfrekvenciaválasz változása inzulinpumpával kezelt diabeteses betegekben és a kontrollcsoport értéke

mutatott az AN összesített súlyosságát kifejező score értékkel (1. ábra). A statisztikai eredmény arra utal, hogy a hosszabb, rossz anyagcsere-körülmények között töltött diabetestartam esetén súlyosabb volt az AN összesített mértéke.

A diabetestartam és a legérzékenyebb paraszimpatikus teszt eredménye, a légzésre bekövetkező szívfrekvencia-válasz is szignifikáns összefüggésben volt egymással a pumpa felhelyezésének idejében (2. ábra). A korreláció negatív, ami arra utal, hogy minél alacsonyabb volt a szívfrekvencia-változás mértéke, annál hosszabb volt a diabetes fennállása.

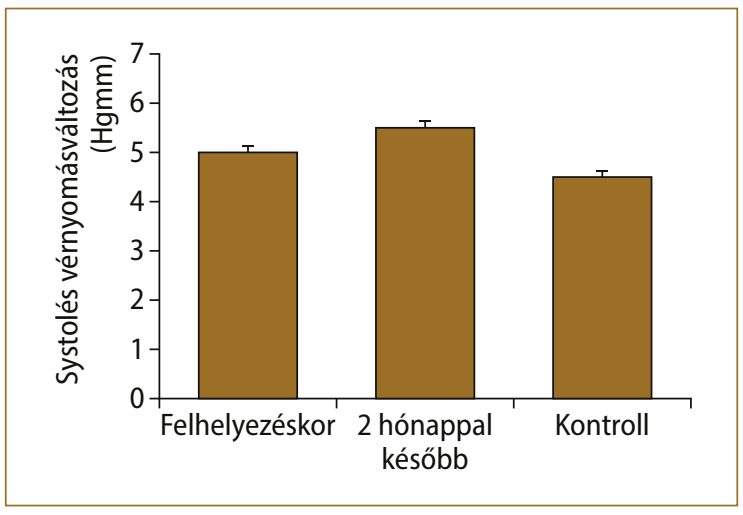

7. ábra. A felállásra bekövetkező systolés vérnyomásváltozás inzulinpumpával kezelt diabeteses betegekben és a kontrollcsoport értéke 
A követés során azt észleltük, hogy az összesített AN score a pumpafelhelyezés után két hónappal kismértékű, de szignifikáns csökkenést mutatott (3. ábra). A betegek kiinduláskor és a követés időpontjában mért értékeit az egészséges kontrollal összehasonlítva megállapítható, hogy mindkét időpontban mérsékelt súlyosságú autonóm neuropathia volt detektálható, amely csökkenő tendenciát mutatott 2 hónapos pumpakezelés után.

A belégzésre bekövetkező szívfrekvencia-válasz követésekor azt találtuk, hogy ennek értéke szignifikánsan javult a két hónapos pumpakezelés során (4. ábra), ami a paraszimpatikus működés javulására utal ezen időszak alatt. Mind a kiinduláskor, mind két hónap múlva a teszt eredményei elmaradtak az egészséges személyek értékeitől.

A további reflextesztek esetében konzekvensen azt figyeltük meg, hogy a Valsalva-hányadosra és a felállásra bekövetkező szívfrekvencia-változás, továbbá a felállásra létrejövő systolés vérnyomásesés nem változott szignifikánsan a 2 hónap alatt, és az egészséges kontrollhoz képest sem bizonyultak kórosabbnak (5., 6. és 7. ábra).

A betegek $\mathrm{HbA}_{1 \mathrm{c}}$-értéke a 2 hónapos követés

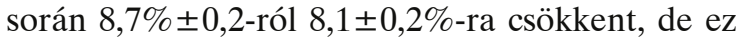
a változás nem volt szignifikáns.

\section{Megbeszélés}

A kedvezőtlen anyagcserehelyzet az autonóm neuropathia kialakulásának kockázatát növeli. A 3004 beteg adatait feldolgozó EURODIAB IDDM vizsgálatban az autonóm neuropathia előfordulása 36\%-nak bizonyult, 2 kóros teszt 6\%-ban, 1 kóros teszt $30 \%$-ban fordult elő. ${ }^{5}$ A paraszimpatikus autonóm neuropathia prevalenciája nem csak a $\mathrm{HbA}_{1 \mathrm{c}}$-vel, de számos egyéb paraméterrel is szignifikáns összefüggést mutatott, amelyek közé a diabetestartam is tartozott. A vizsgálatunkban részt vevő 1-es típusú diabeteses betegek mindegyikének esetében a korábbi terápiás törekvések ellenére sem sikerült stabil anyagcsere-állapotot elérni, ezért vált szükségessé az inzulinpumpa-kezelés bevezetése. Valamennyi betegünk fiatal volt. Az általunk végzett vizsgálatban az években kifejezett betegségtartam és az autonóm neuropathia súlyossága között derült ki szignifikáns összefüggés, ami az irodalmi adatokkal egybevetve arra utal, hogy mind a prevalencia, mind a neuropathia súlyossága összefügg a krónikus anyagcserezavar hosszával. A nagy glükózvariabilitás mértékének és a kardiovaszkuláris reflextesztek kórosságának pozitív öszszefüggése 1-es típusú diabetesben korábban már igazolást nyert. ${ }^{15} \mathrm{Az}$ autonóm neuropathia súlyosságának abszolút értékét illetően vizsgálatunkban a több mint 10 éves diabetestartam és a pumpakezelést szükségessé tevő anyagcsere mellett mérsékelt súlyosságú idegkárosodás jött létre. Az egyes reflexteszteket szeparáltan vizsgálva megállapítottuk, hogy a mély belégzésre bekövetkező szívfrekvencia-válasz szignifikáns negatív összefüggést mutatott a betegségtartammal. A mély be- és kilégzésre bekövetkező szívfrekvencia-változás a paraszimpatikus innervatio vizsgálatára szolgál, és ez tekinthető a legszenzitívebb metodikának ezen funkciózavar megítélése szempontjából. A nagyfokú szenzitivitás miatt a legkorábban kórossá váló tesztnek bizonyul az AN vizsgálata során. ${ }^{16}$ Egyes vélemények szerint ez a teszt önmagában is alkalmas lehet az autonóm neuropathia detektálására, a többi procedúra egyidejü elvégzése inkább a súlyosság mértékének meghatározásában nyújthat segítséget. ${ }^{17,18}$ A negatív korreláció azt mutatja, hogy minél hosszabb ideje tartott a diabetes, annál kisebb volt a légzésre bekövetkező szívfrekvencia-változás mértéke. A többi reflexteszt és a betegségtartam között nem találtunk összefüggést. Az adatok arra utalnak, hogy ebben a betegcsoportban a pumpafelhelyezésig tartó diabetesexpozíció mérsékelt fokú AN-t okozott, amelynek első manifesztációjaként a paraszimpatikus működés károsodott. A paraszimpatikus károsodás mielőbbi csökkentése a kardiovaszkuláris kockázat mérséklését is eredményezi, mivel ilyenkor relatív szimpatikotónia is fennáll, ami a szív-érrendszer szempontjából kifejezetten rossz prognózist jelent. ${ }^{19}$

Vizsgálatunk követéses részében 2 hónapos pumpakezelést követően az autonóm score szignifikáns csökkenését észleltük. Ez az adat arra utal, hogy a mérsékelt autonóm károsodás globálisan csökkent. Az egyes reflexteszteket vizsgálva pedig megállapítható, hogy a paraszimpatikus működés mutatott leginkább javulást 60 nap alatt. Azok az adatok, amelyek azt mutatják, hogy az egyes perifériás vagy autonóm idegrendszerben működő neuronok funkciói akár párórás anyagcserezavar esetén is romlanak, illetve a krónikus hyperglykaemia 
elhárítása után napokon vagy heteken belül is javulnak, koherensek megfigyeléseinkkel. A 2 hónap alatt a hyperglykaemiára legérzékenyebb paraszimpatikus működés már javulást mutat, ami az anyagcserezavar 1-es típusú diabetesben leghatékonyabb javítását biztosító pumpakezelés révén valósult meg. A $\mathrm{HbA}_{1 \mathrm{c}}$ nem szignifikáns mértékben csökkenő tendenciát mutatott, ami támogatja az anyagcserezavar javulásának szerepét. A glykaemiás állapot változását leginkább a glükózvariabilitás követésével tudtuk volna megjeleníteni, azonban ez nem történt meg a jelenlegi vizsgálatban, ami a vizsgálat limitációjának is tekinthető. A dolgozat további korlátja a pumpakezelés rövid időtartama, ugyanakkor a két hónap során bekövetkező változások dokumentálása érdemesnek tűnt.

Összefoglalásként megállapíthatjuk, hogy mérsékelt súlyosságú autonóm neuropathia jellemezte az 1-es típusú diabeteses betegeket pumpakezelésük kezdetekor, amikor anyagcseréjük terápiaváltoztatást tett szükségessé. A diabetestartam konzekvens összefüggést mutatott a paraszimpatikus neuropathia súlyosságával, amely a korai autonóm idegrendszeri károsodás manifesztációjaként alakul ki. A két hónapos pumpakezelés alatt az autonóm funkció javult. Eredményeink szerint az anyagcsere-állapot pumpakezelés során bekövetkező viszonylag gyors javulása már rövid idő alatt mérsékelheti az autonóm idegrendszer működészavarát, hosszabb távon pedig feltételezhetően lassíthatja a neuropathia progresszióját. A szénhidrát-anyagcsere stabilizálása tehát az egyik eszköz lehet az autonóm egyensúly felborulásával létrejövő kardiovaszkuláris kockázat - akár rövid időn belül bekövetkező - csökkentésének 1-es típusú diabetesben.

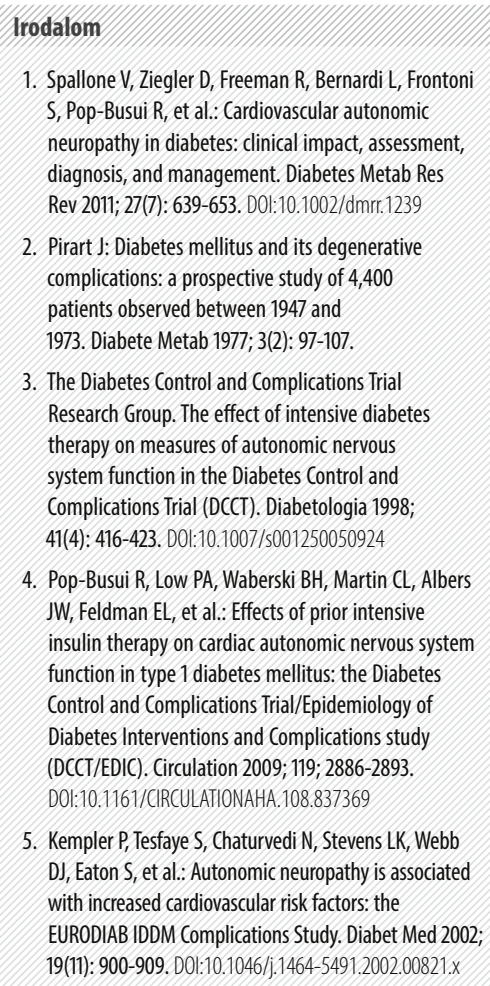

6. Intensive blood-glucose control with sulphonylureas or insulin compared with conventional treatment and risk of complications in patients with type 2 diabetes (UKPDS 33). UK Prospective Diabetes Study (UKPDS) Group. Lancet 1998; 352(9131): 837-853. D01:10.1016/50140-6736(98)07019-6

7. Service FJ, Rizza RA, Daube JR, O'Brien PC, Dyck PJ: Near normoglycaemia improved nerve conduction and vibration sensation in diabetic neuropathy. Diabetologia 1985; 28(10):722-727. D01:10.1007/BF00265018.

8. Kitano Y, Kuwabara S, Misawa S, Ogawara K, Kanai $K$, Kikkawa Y, et al.: The acute effects of glycemic control on axonal excitability in human diabetics. Ann Neurol 2004; 56(4): 462-467. D01:10.1002/ana.20232

9. Fujita Y, Fukushima M, Suzuki H, Taniguchi A, Nakai Y, Kuroe A, et al.: Short-term intensive glycemic control improves vibratory sensation in type 2 diabetes. Diabetes Res Clin Pract 2008; 80(1): e16-19. D01:10.1016/j.diabres.2007.12.011

10. Santini V, Ciampittiello G, Gigli F, Bracaglia D, Baroni A, Cicconetti E, et al.: QTC and autonomic neuropathy in diabetes: effects of acute hyperglycaemia and n-3 PUFA. Nutr Metab Cardiovasc Dis 2007; 17(10): 712-718. D01:10.1016/j.numecd.2006.09.006

11. Marfella R, Nappo F, De Angelis L, Siniscalchi M, Rossi $\mathrm{F}$, Giugliano D: The effect of acute hyperglycaemia on QTc duration in healthy man. Diabetologia 2000; 43(5): 571-575. D01:10.1007/s001250051345

12. Yeap BB, Russo A, Fraser RJ, Wittert GA, Horowitz M: Hyperglycemia affects cardiovascular autonomic nerve function in normal subjects. Diabetes Care 1996; 19(8): 880-882. D01:10.2337/diacare.19.8.880
13. Lam WF, Muller ES, Souverijn JH, Lamers CB, Masclee AA: Effect of acute hyperglycaemia on basal and fatinduced exocrine pancreatic secretion in humans. Clin Sci (Lond) 1997; 93(6): 573-580. D01:10.1042/cs0930573

14. Ewing DJ, Clarke BF: Diagnosis and management of diabetic autonomic neuropathy. Br Med J (Clin Res Ed) 1982; 285(6346): 916-918. D01:10.1136/bmj.285.6346.916

15. Nyiraty S, Pesei F, Orosz A, Coluzzi S, Vági OE, Lengyel C, et al.: Cardiovascular Autonomic neuropathy and glucose variability in patients with type 1 diabetes: Is there an association? Front Endocrinol (Lausanne) 2018; 9: 174. D01: 10.3389/fendo.2018.00174

16. Bernardi L, Spallone V, Stevens M, Hilsted J, Frontoni S, Pop-Busui R, et al.: Methods of investigation for cardiac autonomic dysfunction in human research studies. Diabetes Metab Res Rev 2011; 27(7): 654-664. D01:10.1002/dmr.1224

17. Bellavere F, Bosello G, Cardone C, Girardello $L$, Ferri M, Fedele D: Evidence of early impairment of parasympathetic reflexes in insulin dependent diabetics without autonomic symptoms. Diabete Metab 1985; 11(3): 152-156.

18. Kempler P, Váradi A, Tamás Gy: Which battery of cardiovascular autonomic function tests - suggestion for a rational diagnostic model. Diabetologia 1990; 33(10): 640. D01:10.1007/BF00400214

19. Spallone V: Update on the impact, diagnosis and management of cardiovascular autonomic neuropathy in diabetes: what is defined, what is new, and what is unmet. Diabetes Metab J 2019; 43(1): 3-30. D01:10.4093/dmj.2018.0259 